\title{
Titanium minerals in Cameroon
}

\author{
Christian Knudsen, Joseph Penaye, Martin Mehlsen, Roger K. McLimans and Feiko Kalsbeek
}

The mineral rutile $\left(\mathrm{TiO}_{2}\right)$ is a major ore of titanium, which is used in products such as white pigment and titanium metal. The global consumption of titanium minerals in 2011 was c. 6.7 million tonnes of which 0.7 million tonnes were rutile and 6 million tonnes ilmenite $\left(\mathrm{TiFeO}_{3}\right)$. Rutile is almost pure $\mathrm{TiO}_{2}$ and therefore more valuable than ilmenite (c. $1500 \$ / t$ and $300 \$ / t$, respectively). Compared with ilmenite, rutile can be processed with lower consumption of chemicals and yields less waste products. Rutile was mined in Cameroon between 1935 and 1955 when a total of 15000 tonnes of rutile were extracted from alluvial deposits. The French Bureau de Recherches Géologiques et Minières conducted a drilling programme in Cameroon in the 1980s which identified c. 2.6 million tonnes of rutile in discontinuous occurrences with concentrations of $c .1 \%$. Most of the occurrences are located in small- to medium-sized riverbeds with a thickness of $1.5-4.5 \mathrm{~m}$. The main alluvial rutile area is located around the town of Akonolinga, $80 \mathrm{~km}$ east of Yaoundé, the capital of Cameroon (Fig. 1). The rutile in the alluvial deposits was derived from the bedrock by weathering, and at some sites major, residual rutile deposits are reported from Quaternary lateritic deposits.

The Geological Survey of Denmark and Greenland conducted a project together with the Institut de Recherches Géologiques et Minières in Cameroon to gain a better understanding of how rutile formed in the bedrock before it was weathered out and try to tie the rutile in the alluvial deposits to its source rocks. This is done by studying the compositional variation of the rutile in the alluvial deposits and comparing it with possible bedrock sources. The compositional variation of ilmenite and monazite $\left.\left((\mathrm{La}, \mathrm{Ce}) \mathrm{PO}_{4}\right)\right)$ and the age distribution of zircon $\left(\mathrm{ZrSiO}_{4}\right)$ in alluvial sand and bedrock were also investigated. The chemical compositions of minerals in the sediments are used to infer the bedrock source of the minerals. This has particular application in many areas of Cameroon, such as the southern part of the country which is characterised by low relief and dense rain forest with bedrock outcrops that are sparse and difficult to find.

Cameroon is a country in west central Africa (Fig. 1) and is called 'Africa in miniature' because of its cultural, geological and landscape diversity. The landscape includes beaches, deserts, mountains, rain forests and savanna. The highest point is the active volcano Mount Cameroon (4095 m), and the country is home for over 200 different linguistic groups with French and English as the official languages. Compared with other African countries, Cameroon is politically and socially stable. The country covers an area of $475442 \mathrm{~km}^{2}$ with a population of $c .20$ million of which $70 \%$ are Christians and $20 \%$ Muslims.

\section{Geochronology of the Yaoundé Group}

Stendal et al. (2006) suggested that the rutile in southern Cameroon is associated with the Neoproterozoic Yaoundé Group that primarily consists of garnet-bearing metamorphosed sediments such as shale and sandstone. These

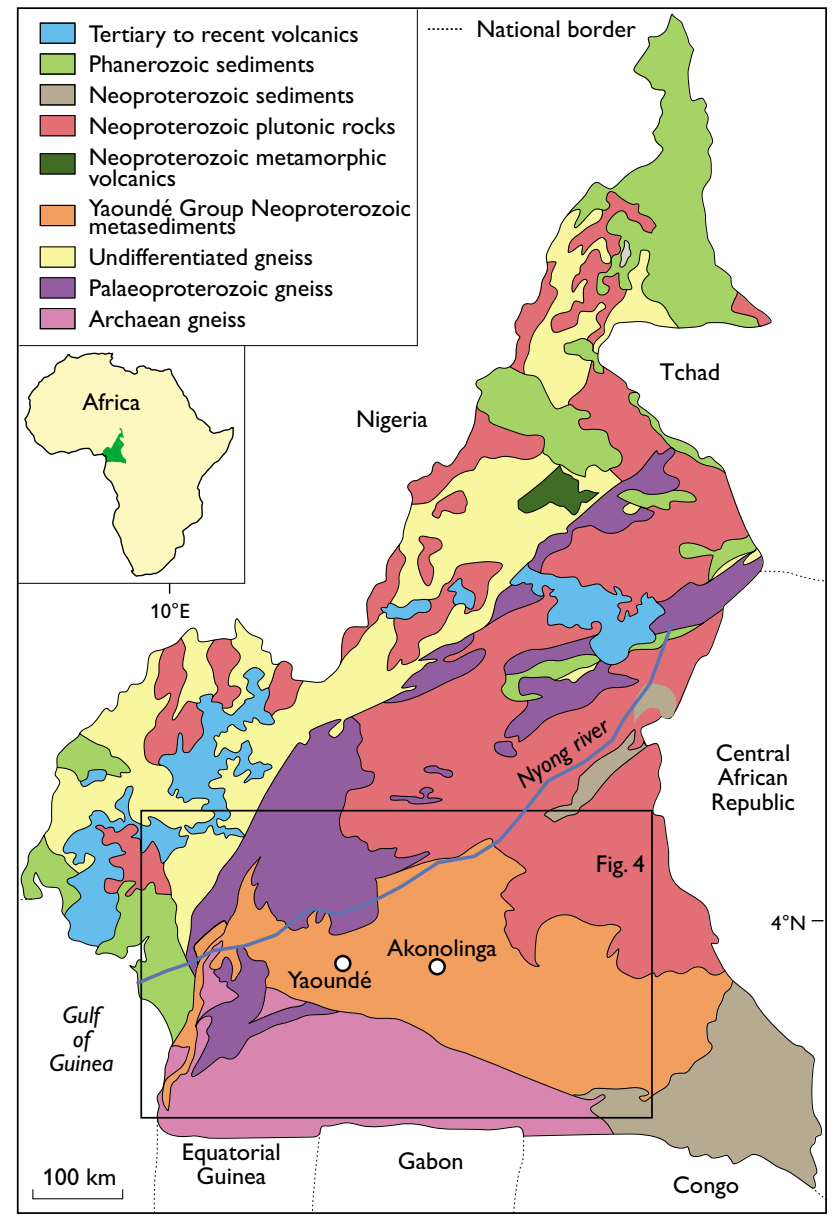

Fig. 1. Simplified geological map of Cameroon. 
sediments are believed to have been deposited on the passive margin of the Congo Craton (Nzenti et al. 1988), and available isotope data suggest that the sediments that formed the precursor of the Yaoundé Group were deposited during Late Neoproterozoic time. Toteu et al. (2004) interpreted some of the sediments as deposited between 626 and $600 \mathrm{Ma}$.

In order to elucidate the timing of deposition and metamorphism of the Yaoundé Group, zircons from three samples of the Yaoundé Group have been dated by laser ablation inductively coupled plasma mass spectrometry at the Geological Survey of Denmark and Greenland (Kalsbeek et al. 2013; for analytical procedures see Frei et al. 2006). The results for one of the samples, a garnet-kyanite gneiss (GGU 512411), are shown in Fig. 2. Zircon grains from this sample have wide metamorphic rims which surround cores that are interpreted to represent remnants of originally detrital grains (inset in Fig. 2). The rims yielded a weighted mean age of $635 \pm$ $10 \mathrm{Ma}(\mathrm{N}=41$, MSWD $=0.48)$. Most of the cores are of Neoproterozoic age (mainly 650-1100 Ma); a small number of Palaeoproterozoic zircon grains are also present. In contrast to GGU 512411, two other samples from the Yaoundé Group (GGU 512401 and 512415) did not yield zircon ages younger than c. $950 \mathrm{Ma}$. Most zircon grains from these samples are of Palaeoproterozoic age, but some Mesoproterozoic and Archaean grains are also present. The different detrital zircon age distributions indicate different source areas of the Yaoundé Group sediments. One source area may have been dominated by either Palaeoproterozoic or Neoproterozoic zircon grains, and another source area showed diverse age distribution patterns with Archaean to Neoproterozoic zircon grains.

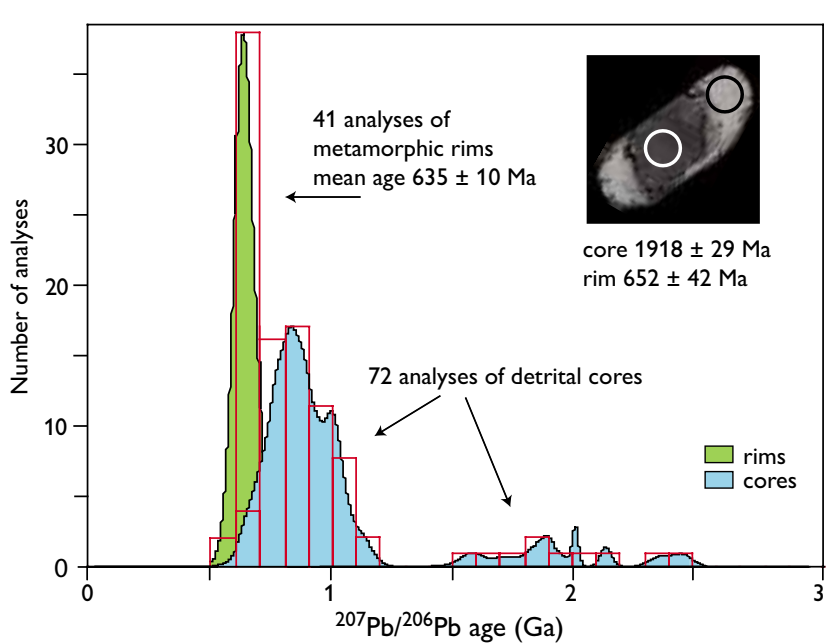

Fig. 2. ${ }^{207} \mathrm{~Pb} /{ }^{206} \mathrm{~Pb}$ age distribution (Sircombe 2004) of zircons from sample GGU 512411 from the Yaoundé Group. The inset shows a zircon grain with a distinct metamorphic rim. Ages of cores and rims are shown separately; for simplicity no distinction is made between concordant and discordant analyses.

\section{The rutile-forming event}

The metamorphic event that affected the sediments was related to the Pan-African orogeny and the formation of the Gondwana supercontinent. In Cameroon, the Pan-African orogeny was caused by the collision of the Congo Craton to the south with the Nigerian Shield to the north. In the areas where placer rutile deposits are found, the bedrock often consists of kyanite-bearing mica schist, indicating high-pressure, metamorphic conditions during this orogeny. Rutile occurs together with garnet and kyanite and was formed by breakdown of titanium-bearing minerals such as ilmenite, biotite and muscovite. In Cameroon, the rutile is commonly located within kyanite and garnet crystals (Fig. 3)

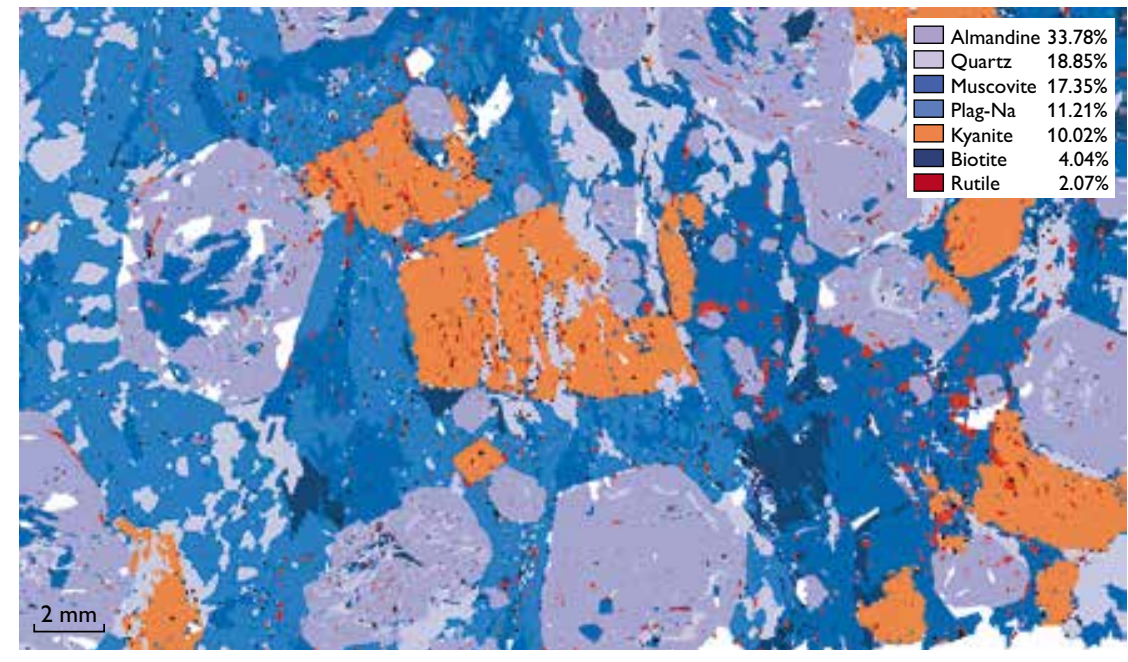

Fig. 3. Mineral Liberation Analysis (MLA) image of a kyanite garnet gneiss sample (GGU 512921) in which the rutile is enclosed in both garnet and kyanite; this indicates that the rutile was formed during prograde metamorphism i.e. during increasing pressure and temperature. MLA is a scanning electron microscope-based method where a polished, mounted part of the sample is divided into $10 \times 10 \mu \mathrm{m}$ pixels. The beam of electrons generates an X-ray spectrum, which is subsequently compared with a library of spectra representing different minerals. In this way, the instrument can recognise the minerals in the sample and generate an image of the mineralogy. The MLA technique was described by Fandrich et al. (2007). 
Fig. 4. Pie diagrams showing temperatures during formation based on the $\mathrm{Zr}$ content in rutile from 18 rock samples from the Yaoundé Group The calculation of the temperature $T$ (in $\left.{ }^{\circ} \mathrm{C}\right)=$ $127.8 \times \ln (\mathrm{Zr}$ in rutile in ppm) -10 is based on Zack et al. (2004). YG: Yaoundé Group. For location see Fig. 1.

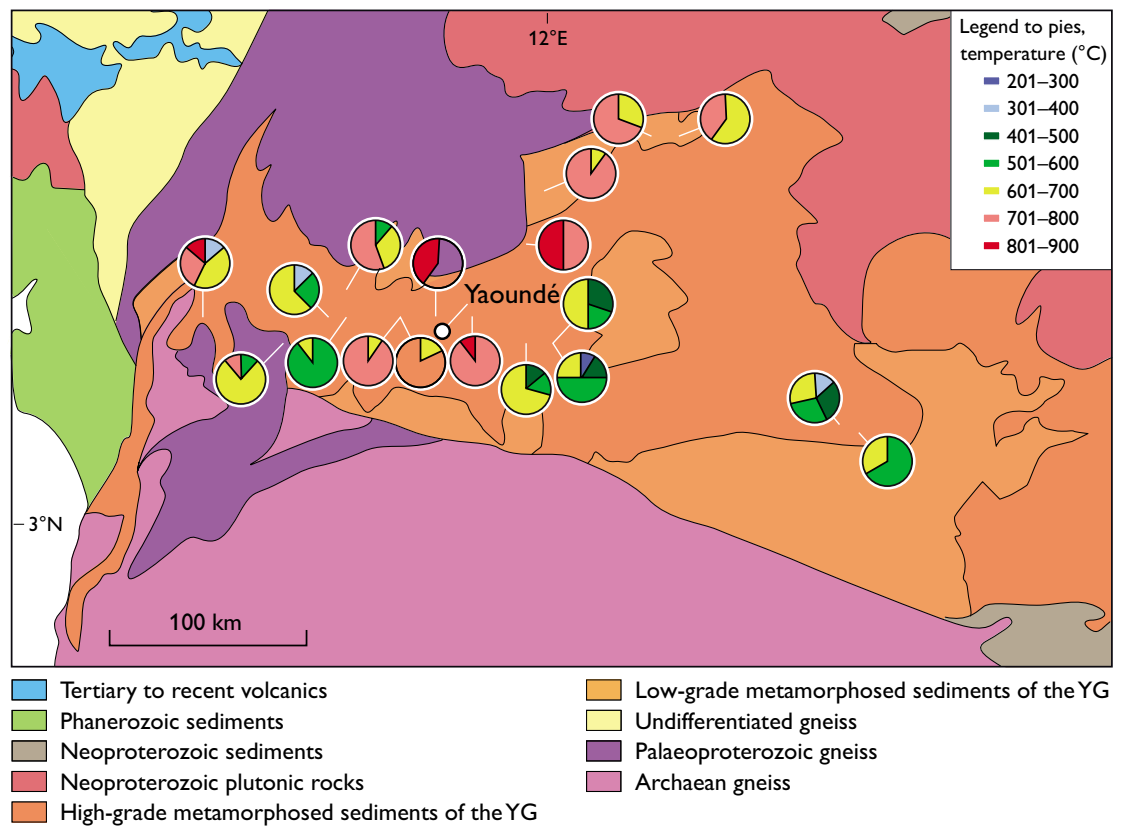

that formed during high-pressure metamorphism, and thus rutile must have formed during the same episode when pressure and temperature were rising (prograde metamorphism). However, it is possible that some of the rutile grains in the rocks of the Yaoundé Group are inherited from older rocks, as suggested by Stendal et al. (2006).

The temperature of rutile formation can be inferred from the rutile geothermometer (Zack et al. 2004; Tomkins et al. 2007). Eighteen rutile-bearing rock samples from the Yaoundé Group were studied. As shown in Fig. 4, the temperature during formation of the rutile varies significantly. The geographical distribution of the temperatures appears

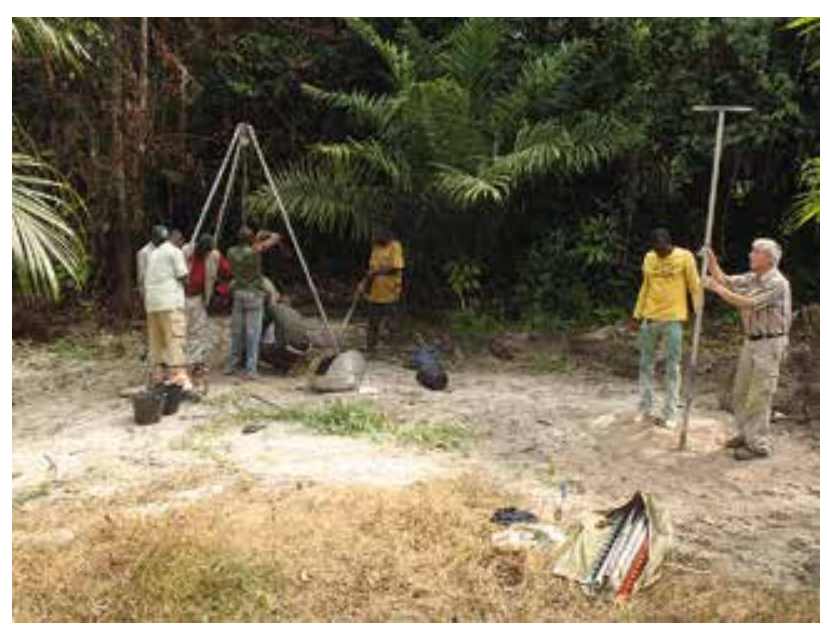

Fig. 5. Two sampling methods being tested. Left: a light auger driven by a small engine mounted on a tripod; right: a hand auger. At this location, the hand auger was superior as it penetrated $4.5 \mathrm{~m}$ in 30 minutes whereas the engine-driven auger penetrated $2 \mathrm{~m}$ during the same time. to show a pattern with a core area around Yaoundé characterised by high temperatures in the $700-900^{\circ} \mathrm{C}$ range with areas to the north-east and south-west characterised by temperatures of $600-700^{\circ} \mathrm{C}$. Both east and west of the core area, the estimated temperatures of formation are lower, mainly in the range $500-700^{\circ} \mathrm{C}$. It is not known if there was only one episode of rutile formation. Geochronological work on the rutile is planned to test if it is possible to tie the formation of the rutile in the area to the Pan-African orogeny.

\section{Sediment sampling and analysis}

A programme combining collection of sediment samples from modern rivers and sampling of older river deposits was initiated in an area in the southern part of Cameroon (Figs $1,4)$. The samples from streams were collected as heavy mineral concentrates, and the alluvial deposits were sampled using either a light auger driven by a small engine mounted on a tripod or a hand auger (Fig. 5). The samples were analysed for major and trace elements using X-ray fluorescence and inductively coupled plasma mass spectrometry, respectively. The ratio between $\mathrm{TiO}_{2}$ and $\mathrm{Fe}_{2} \mathrm{O}_{3}$ was used to identify areas where the titanium is primarily located in rutile. The results show that areas with a $\mathrm{TiO}_{2} / \mathrm{Fe}_{2} \mathrm{O}_{3}$ ratio $>2$ in stream sediments and alluvial deposits coincide with areas where Yaoundé Group sediments are found below the surficial deposits.

In order to study the texture of the titanium mineral grains in stream sediments and alluvial sand, samples were subjected to 'Mineral Liberation Analysis' (Fig. 6). The analysis shows that the detrital rutile grains often have a rim of ilmenite. This is also seen in rock samples from the area 


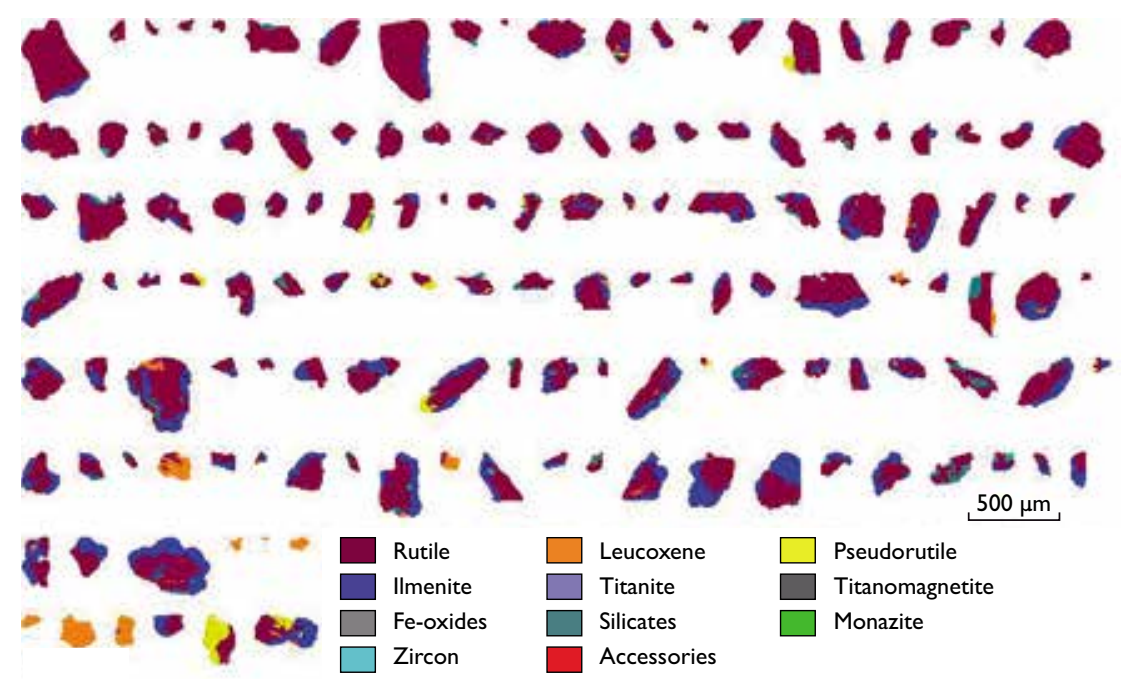

Fig. 6. Mineral Liberation Analysis image of detrital grains from Nyong river in Cameroon (GGU 517615). The purple coloured parts are rutile and the blue is ilmenite. The orange grains are altered ilmenite grains (leucoxene).

where rutile is overgrown by ilmenite. This is caused by recrystallisation of the rock under lower-grade metamorphic conditions, probably retrogression during the late part of the Pan-African orogeny.

\section{Conclusions}

The titanium mineral rutile was formed by high-grade metamorphism of sedimentary rocks of the Neoproterozoic Yaoundé Group during the Pan-African orogeny c. $635 \mathrm{Ma}$ ago. The temperature of the rutile-forming event has been estimated using the 'rutile geothermometer' based on the $\mathrm{Zr}$ content in the rutile, and it is found that the highest temperatures $\left(c .750 \pm 100^{\circ} \mathrm{C}\right)$ are found in the area from Yaoundé towards the north-east. Both north-west and south-east of this area the rutile geothermometer indicates lower metamorphic temperatures $\left(c .600 \pm 100^{\circ} \mathrm{C}\right)$.

\section{Acknowledgements}

We thank J.V. Hell, Director of Institut de Recherches Géologiques et Minières in Cameroon for enthusiastic support and permission to use vehicles from the institute during the field work. J. Boserup constructed the small tripod drillrig and Alfons Berger assisted with the Electron Microprobe analyses at the Department of Geosciences and Natural Resource Management, University of Copenhagen. We thank J.Z. Johansen, J.M.U.O. Njel and B. Kankeu for help during field work in Cameroon. DuPont Titanium Technologies, Wilmington, Delaware, USA, provided financial support.

\section{References}

Fandrich, R., Gu, Y., Burrows, D. \& Moeller, K. 2007: Modern SEMbased mineral liberation analysis. International Journal of Mineral Processing 84, 310-320.

Frei, D., Hollis, J.A., Gerdes, A., Harlov, D., Karlsson, C., Vasques, P., Franz, C., Johansson, L. \& Knudsen, C. 2006: Advanced in situ geochronological and trace element microanalysis by laser ablation techniques. Geological Survey of Denmark and Greenland Bulletin 10, 25-28.

Kalsbeek, F., Ekwueme, B.N., Penaye, J., de Souza, Z.S. \& Thrane, K. 2013: Recognition of Early and Late Neoproterozoic supracrustal units in West Africa and North-East Brazil from detrital zircon geochronology. Precambrian Research 226, 105-115.

Nzenti, J.P., Barbey, P., Macaudière, J. \& Soba, D. 1988: Origin and evolution of the late Precambrian high-grade Yaoundé gneisses (Cameroon). Precambrian Research 38, 91-109.

Sircombe, K.N. 2004: AgeDisplay: an Excel workbook to evaluate and display univariate geochronological data using binned frequency histograms and probability density distributions. Computers \& Geosciences 30, 21-31.

Stendal, H., Toteu, S.F., Frei, R., Penaye, J., Njel, U.O., Bassahak, J., Nni, J., Kankeu, B., Ngako, V. \& Hell, J.V. 2006: Derivation of detrital rutile in the Yaoundé region from the Neoproterozoic Pan-African belt in southern Cameroon (Central Africa). Journal of African Earth Sciences 44, 443-458.

Tomkins, H.S., Powell, R. \& Ellis, D.J. 2007: The pressure dependence of the zirconium-in-rutile thermometer. Journal of Metamorphic Geology 25, 703-713.

Toteu, S.F., Penaye, J. \& Djomani, Y.P. 2004: Geodynamic evolution of the Pan-African belt in central Africa with special reference to Cameroon. Canadian Journal of Earth Sciences 41, 73-85.

Zack, T., Moraes, R. \& Kronz, A. 2004: Temperature dependence of Zr in rutile: empirical calibration of a rutile thermometer. Contributions to Mineralogy and Petrology 148, 471-488.

\footnotetext{
Authors' addresses

C.K., F.K. \& M.M., Geological Survey of Denmark and Greenland, Øster Voldgade 10,DK-1350 Copenhagen K, Denmark. E-mail: ckn@geus.dk J.P., Institut de Recherches Géologiques et Minières, Rue Mgr Vogt, P.O. Box 4110 Nlongkak, Yaoundé, Cameroon.

R.K.McL., DuPont Titanium Technologies, Experimental Station, E352/217, Route 141 and Henry Clay Road, Wilmington, DE 19808, USA.
} 